\title{
PREVALENCE OF HEPATITIS C INFECTION AMONG DIABETICS TYPE 2 AT SHARKIA GOVERNORATE, EGYPT
}

\author{
Essam M Amin MD, Adel AM Ghorab MD, Mohamed S Mohamed MSc, Amal A. Zidan MD*. \\ Internal Medicine and Clinical Pathology* Departments, Faculty of Medicine, \\ Zagazig University Hospital, Egypt
}

\begin{abstract}
Background: HCV virus infection and type 2 diabetes mellitus are two major public health problems in Egypt. Egypt has the highest HCV virus prevalence in the world and is considered the ninth in rank of the highest prevalence of diabetes worldwide. The mutual relationship between diabetes and increased HCV infection may be due to the association of $\mathrm{HCV}$ with hepatic steatosis, insulin resistance and decrease of adiponectine synthesis as well as the nature of diabetes and its inherent complications and/or frequent parental exposure.

Objective: determination of the prevalence of HCV infection in type-2 diabetics in Sharkia Governorate and to explore the predominant risk factors for $\mathrm{HCV}$ infection and its relation to some demographic parameters of this locality.

Subjects and methods: A cross sectional randomized study was conducted to 642 patients, regardless of gender, body weight, educational level or socioeconomic levels, at multicentre managing diabetic patients at Sharkia governorate. All patients were subjected to detection of $\mathrm{HCV}$-ab by third generation ELISA and HBA1C level

\section{Results:}

The prevalence of HCV infection among type 2 diabetic patients at Sharkia governorate approximates 38.7 $\%$. Higher prevalence was detected among patients between 45 \& 65 years old, low socioeconomic level, low educational level, and those who share personal utensils, have other family members infected with HCV. Patients who previously transfused, previous hospitalized, previously received parenteral anti-bilharzial therapy and those receiving insulin injections are also at high risk.

Conclusion: As high as 39\% of type-2 diabetics at Sharkia Governorate are HCV-infected. Apart from classic risk factors, The most significant independable factors associated with development of HCV infection in type 2 diabetics are low socioeconomic standard and low educational level. Previous blood transfusion, family members infected with $\mathrm{HCV}$, parenteral antibilharzial treatment, sharing personal utensils and previous hospitalization may play also a role.
\end{abstract}

Key words: Hepatitis $C$ virus, Type 2 diabetes, Prevalence

\section{INTRODUCTION}

$\mathbf{H}$ epatitis $\mathrm{C}$ virus (HCV) infection is an important public health problem affecting more than 170 million peoples worldwide ${ }^{(\mathbf{1})}$. It is a major public health challenge in Egypt. It is estimated that $\mathrm{HCV}$ prevalence among the 15-59 years age group to be $14.7 \%$ which is said to be the highest prevalence in the world ${ }^{(2)}$.

Diabetes is considered to be one of the most common chronic diseases and a growing public health challenge globally, where an estimated 382 million people, corresponding to $8.3 \%$ of the world's adult population, has diabetes and it is further expected that by the year 2035, 592 millions of the population would have diabetes corresponding to around $8.8 \%$ of the adult population ${ }^{(3)}$. Type 2 diabetes (T2DM), which is characterized by insulin resistance accounts for 90-95\% of all diabetics. Diabetes is considered to be the seventh leading cause of death in the United States ${ }^{(4)}$.

It is estimated that by the year 2030, Egypt will have at least 8.6 million adults with diabetes.
Diabetes is the eleventh most important cause of premature mortality in Egypt, and is responsible for $2.4 \%$ of all years of life lost (YLL). Similarly, diabetes is the sixth most important cause of disability burden in Egypt ${ }^{(5)}$.

A link between diabetes and liver disease has been suggested for a very long time. Diabetes was found to be an important cause of liver disease, where patients with diabetes were found to have a spectrum of liver diseases, ranging from abnormal liver enzymes, nonalcoholic fatty liver disease, cirrhosis, hepatocellular carcinoma, and acute liver failure, all associated with the increased prevalence of hepatic complications including liver cirrhosis and portal hypertension ${ }^{(6)}$. On the other hand liver disease was considered to be an important cause of death in T2DM, where in one prospective cohort study, cirrhosis accounted for $12.5 \%$ of all death causes ${ }^{(7)}$.

Since HCV infection was identified, numerous epidemiological studies have reported a higher prevalence of diabetes mellitus type 2 (DM2) among HCV- infected patients, although, the 
initial association of DM2 and liver disease was established and confirmed in patients with advanced liver diseases long time ago ${ }^{(8)}$. Several studies from different parts of the world have found that $13 \%$ to $33 \%$ of patients with chronic HCV have associated diabetes, mostly type 2 DM (9), Chronic HCV, not chronic HBV, can be considered not only a viral disease, but also a special type of metabolic disease ${ }^{(\mathbf{1 0})}$.

No one can expect, who come first; chronic HCV or DM2 but, it is so clear that, chronic HCV is usually associated with hepatic steatosis, insulin resistance and decrease of adiponectine synthesis that all predispose persons chronically infected with HCV to gradual development of DM2 ${ }^{(11)}$. In the other side, diabetic patients are at high risk of $\mathrm{HCV}$ infection from frequent parenteral exposure as they are regular visitors to dentists and have frequent surgical exposures ${ }^{(\mathbf{1 2}) \text {. }}$

As hepatitis c infection is endemic in Egypt specially in Sharkia governorate, and there is no previous study done in Sharkia governorate to detect the prevalence of $\mathrm{HCV}$ in type 2 diabetic patients so it has become very necessary for a screening exercise to determine the prevalence rate of HCV among diabetic patients type 2 in Sharkia and the relation of hepatitis $\mathrm{C}$ infection to some demographic parameters, diabetes control and diabetic complications and detect some of the risk factors of infection in these patients so as to increase awareness of the population and health practitioners of the dangers of the co-infectious state of this virus with diabetes and the importance of following the infection control parameters for $\mathrm{HCV}$.

\section{SUBJECTS AND METHODS}

This is cross sectional randomized study conducted at multicenter managing diabetic patients at Sharkia governorate

- Sharkia governorate is divided into 14 districts Zagazig and Heihia districts were randomly selected.

- Zagazig and Heihia cities were randomly selected representing urban areas while Shobak Basta and Sobieh villages were randomly selected from Zagazig and Heihia districts representing rural areas

- Zagazig university hospitals were selected randomly from Zagazig hospitals

- Heihia general hospital, Shobak Basta medical center and sobieh medical center were included representing Heihia, Shobak Basta and sobieh

The study included a total number of 642 patients type $2 \mathrm{DM}$ at Sharkia governorate

\section{Inclusion criteria:}

Type 2 diabetic patients regardless of gender, body weight, educational level or socioeconomic levels were included in the study. The study involved the outpatients and hospitally admitted patients with or without other comorbidities.

\section{Exclusion criteria:}

No exclusion criteria in type 2 diabetic patients

Methods

All patients of this cross sectional study were subjected to the following:

A) Full history taking : with special stress on:

1. demographic parameters \{ age, sex ,residence ,marital state, special habits, socio-economic level, educational level and family size $\}$

2. Risk factors for HCV infection to be confirmed or excluded in all patients like (previous blood transfusion -parenteral anti bilharzial treatment previous operation or surgical or dental maneuver's - previous hospitalization - drugs addiction - sharing personal utensils and type of previous deliveries "for females")

3. Duration of DM and type of treatment ( oral insulin -combined)

4. If the patient knows that he has HCV, duration of infection and if he received treatment or not.

5. Diabetes complication( previous coma, peripheral neuropathy, cardiovascular complication ,renal, ophthalmological ,,,,, )

6. Family history of HCV of other members

B) Thorough clinical examination with stress on:

- Features of jaundice, pallor or bleeding tendency

- Weight and height for calculation of body mass index

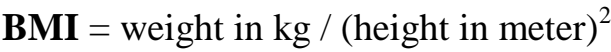

- Diabetic complications (diabetic foot, peripheral neuropathy, cardiovascular...)

- Hepato-biliary examination for liver, spleen size and ascites and stigmata of liver cell failure.

- Other systems involvement.

C) Laboratory investigations:

1. HCV ab testing : within 6 hours of collections blood was separated and the serum was stored in -80 until testing for $\mathrm{HCV}$ ab serum samples were later thawed and tested for anti $\mathrm{HCV}$ antibodies with a third generation enzyme linked immunosorbent assay (ELISA).

2. HBA1C testing : $2 \mathrm{ml}$ of blood is collected in EDTA containing tube then mixing each specimen by gentle inversion of the tube to ensure homogeneity, whole blood was stored at 2-8 C before testing for HBA1C (where it can be stable up to fourteen days),

The patients' control of DM is categorized according to HBA1C level to:

Strict controlled HBA1C less than 6.5 
Controlled HBA1C between 6.5 - less than 8 Mild uncontrolled HBA1C between 8 - less than 10

Mod uncontrolled HBA1C between 10 - less than 13

Bad uncontrolled HBA1C more than 13

Statistical Method:

All data were analyzed using SPSS 15.0 for windows (SPSS Inc., Chicago, IL, USA). Continuous data were expressed as the mean \pm SD $\&$ median (range), and the categorical data were expressed as a number (percentage). Continuous data were checked for normality by using Kolmogorov-Smirnov test. Student t-test was used to compare two groups of normally distributed data, Mann-Whitney U (MW) test for two groups of non-normally distributed data. Categorized data were compared using the Chi-square $\left(\chi^{2}\right)$ test.

Odd ratio (OR) was used to estimate risk in univariate model with $95 \%$ confidence interval. If interval contain 1 , the $p$ value of test statistics will be non-significant. A Stepwise logistic regression analysis (SE: Standard Error, OR: Odd Ratio) was performed to assess the influence of various risk factors on HCV infection in multivariate model.

For two tailed tests $\mathrm{P}<0.025$ was considered statistically significant distributed data, $\mathrm{P}<0.001$ was considered highly statistically significant, and $\mathrm{P}>0.025$ was considered non statistically significant. For one tailed tests $\mathrm{P}<0.05$ was considered statistically significant, $\mathrm{P}<0.005$ was considered highly statistically significant, and $\mathrm{P}>$ 0.05 was considered none statistically significant.

\section{RESULTS}

The striking result of the study was the high prevalence of $\mathrm{HCV}$ infection among type II diabetic patients at Sharkia governorate (249 patients out of 642 patients enrolled in the study have $\mathrm{HCV}$ antibodies) with overall prevalence of $38.7 \%$. Although the prevalence in males is little bit higher than females ( $44.2 \%$ vs $36.6 \%$ ), the difference did not reach the statistical significant level $(\mathrm{p}=0.159)$

The prevalence is statistically higher in older age groups with median age of 56 years $(\mathrm{P}=0.0001)$ with the age range between $45-65$ years carrying the higher infection with less percentage as we approach the extremes of ages, as shown in table (1).

The residence place whether urban or rural has no relation with the prevalence of positive infection by $\mathrm{HCV}$ in type 2 diabetic patients, the same result has been observed regarding the smoking as shown in. The study demonstrates clearly that the prevalence of $\mathrm{HCV}$ infection in type 2 diabetic patients was significantly higher in low socioeconomic class patients This is further supported by the anticipated results of higher infection in illiterates and patients having lower educational level and those sharing personal utensils

Family members infected with $\mathrm{HCV}$ is considered an important risk factor for occurrence of $\mathrm{HCV}$, while higher family size per se is not a risk factor for higher $\mathrm{HCV}$ prevalence in type 2 diabetic patients.

In studying the well-known risk factors for getting infected with $\mathrm{HCV}$ the study demonstrated that almost one third $(32.1 \%)$ of patients with positive $\mathrm{HCV}-\mathrm{Ab}$ have a history of previous blood transfusion in versus $20.6 \%$ with $\mathrm{HCV}-\mathrm{Ab}$ negative patients. Also significant association was found between previous hospitalization, parenteral anti-bilharzial therapy \& occurrence of $\mathrm{HCV}$ infection. Higher percent of $\mathrm{HCV}$ positive patients have previous operation but this was nonsignificant. Longer duration of diabetes, receiving insulin injection have associated with increased $\mathrm{HCV}$ prevalence.

No significant association was detected in the studied population between the degree of obesity, DM control, presence of diabetic complications either neurological, cardiovascular, ophthalmological, renal, or diabetic foot and prevalence of $\mathrm{HCV}$ infection.

The astonishing result in this study is the high percentage of $\mathrm{HCV}$ positive patients not known that they have the antibodies and they discovered the infection on participating in the study (51\% of $\mathrm{HCV}$ positive patients) and the vast majority (90\%) of known HCV positive patients did not receive any specific treatment for $\mathrm{HCV}$.

Univariate analysis (table 3 ) revealed significant increase in HCV risk in age group 45-65 years, low socioeconomic level, primary education, previous blood transfusion, sharing personal utensils, previous hospitalization, parenteral antibilharzial, insulin injection, \& presence of family members infected with HCV.

Based on stepwise logistic regression analysis (table 4), significant factors associated with development of $\mathrm{HCV}$ in type II diabetes mellitus patients were low socioeconomic level, previous blood transfusion, family members with $\mathrm{HCV}$, received parenteral antibilharzial treatment, sharing personal utensils, previous hospitalization 
Table (1): Comparison of some demographic parameters and risk factors exposures between HCV positive and HCV negative cases

\begin{tabular}{|c|c|c|c|c|c|c|}
\hline & \multicolumn{2}{|c|}{$\begin{array}{c}\text { HCV ab negative } \\
\quad(n=393)\end{array}$} & \multicolumn{2}{|c|}{$\begin{array}{l}\text { HCV ab } \\
\text { positive } \\
(n=249)\end{array}$} & \multirow[t]{2}{*}{$\chi^{2}$} & \multirow[t]{2}{*}{$p$} \\
\hline & $\mathrm{No}$ & $\%$ & $\mathrm{No}$ & $\%$ & & \\
\hline \multicolumn{7}{|l|}{ Age groups } \\
\hline $25-$ & 25 & $6.4 \%$ & 6 & $2.4 \%$ & \multirow{5}{*}{25.790} & \multirow{5}{*}{$0.0001 *$} \\
\hline $35-$ & 107 & $27.2 \%$ & 37 & $14.9 \%$ & & \\
\hline $45-$ & 136 & $34.6 \%$ & 94 & $37.8 \%$ & & \\
\hline $55-$ & 94 & $23.9 \%$ & 94 & $37.8 \%$ & & \\
\hline $65-$ & 31 & $7.9 \%$ & 18 & $7.2 \%$ & & \\
\hline \multicolumn{7}{|l|}{ Socioeconomic status } \\
\hline Low & 138 & $35.1 \%$ & 110 & $44.2 \%$ & \multirow{3}{*}{8.219} & \multirow{3}{*}{ 0.016* } \\
\hline Mid & 222 & $56.5 \%$ & 129 & $51.8 \%$ & & \\
\hline High & 33 & $8.4 \%$ & 10 & $4 \%$ & & \\
\hline \multicolumn{7}{|l|}{ Education level } \\
\hline Illiterate & 127 & $32.3 \%$ & 77 & $30.9 \%$ & \multirow{4}{*}{19.731} & \multirow{4}{*}{$0.0001 *$} \\
\hline Primary & 84 & $21.4 \%$ & 90 & $36.1 \%$ & & \\
\hline Secondary & 132 & $33.6 \%$ & 55 & $22.1 \%$ & & \\
\hline University & 50 & $12.7 \%$ & 27 & $10.8 \%$ & & \\
\hline \multicolumn{7}{|c|}{ Sharing personal utensils } \\
\hline No & 60 & $15.3 \%$ & 22 & $8.8 \%$ & \multirow[t]{2}{*}{5.660} & \multirow[t]{2}{*}{$0.017 *$} \\
\hline $\begin{array}{c}\text { Yes } \\
\end{array}$ & 333 & $84.7 \%$ & 227 & $91.2 \%$ & & \\
\hline \multicolumn{7}{|c|}{ Family members infected with } \\
\hline $\mathrm{HCV} \quad \mathrm{No}$ & 288 & $73.3 \%$ & 157 & $63.1 \%$ & \multirow[t]{2}{*}{7.500} & \multirow[t]{2}{*}{$0.006 *$} \\
\hline Yes & 105 & $26.7 \%$ & 92 & $36.9 \%$ & & \\
\hline \multicolumn{7}{|c|}{ Previous blood transfusion } \\
\hline No & 312 & $79.4 \%$ & 169 & $67.9 \%$ & \multirow[t]{2}{*}{10.762} & \multirow[t]{2}{*}{$0.001 *$} \\
\hline Yes & 81 & $20.6 \%$ & 80 & $32.1 \%$ & & \\
\hline \multicolumn{7}{|l|}{ Previous Hospitalization } \\
\hline No & 163 & $41.5 \%$ & 74 & $29.7 \%$ & \multirow[b]{2}{*}{9.047} & \multirow[b]{2}{*}{ 0.003* } \\
\hline Yes & 230 & $58.5 \%$ & 175 & $70.3 \%$ & & \\
\hline \multicolumn{5}{|c|}{ Parenteral Anti-Bilharzil therapy } & \multirow{3}{*}{7.963} & \\
\hline No & 122 & $31 \%$ & 52 & $20.9 \%$ & & $0.005 *$ \\
\hline Yes & 271 & $69 \%$ & 197 & $79.1 \%$ & & \\
\hline Type of treatment OF & & & & & & \\
\hline No & 0 & $0 \%$ & 2 & $0.8 \%$ & & \\
\hline Oral & 279 & $71 \%$ & 152 & $61 \%$ & 10.307 & $0.016 *$ \\
\hline Insulin & 90 & $22.9 \%$ & 80 & $32.1 \%$ & & \\
\hline Combined & 24 & $6.1 \%$ & 15 & $6 \%$ & & \\
\hline
\end{tabular}


Table (2):Comparison of the( mean values \pm SD, median and range) of family size and duration of DM between HCV positive and HCV negative cases

\begin{tabular}{|c|c|c|c|c|}
\hline & $\begin{array}{c}\text { HCV ab negative } \\
(n=393)\end{array}$ & $\begin{array}{c}\text { HCV ab } \\
\text { positive } \\
(n=249)\end{array}$ & $\mathbf{t}$ & $p$ \\
\hline \multicolumn{5}{|l|}{ Family size } \\
\hline Mean $\pm S D$ & $5.93 \pm 1.57$ & $6.2 \pm 1.53$ & \multirow{3}{*}{-2.116} & \multirow{3}{*}{0.035} \\
\hline Median & 6 & 6 & & \\
\hline Range & $2-9$ & $2-10$ & & \\
\hline \multicolumn{5}{|l|}{ Duration of DM } \\
\hline Mean $\pm S D$ & $7.4 \pm 6.82$ & $8.76 \pm 7.11$ & \multirow{3}{*}{-2.417} & \multirow{3}{*}{$0.016 *$} \\
\hline Median & 5 & 6 & & \\
\hline Range & $0-30$ & $0-30$ & & \\
\hline
\end{tabular}

Table (3): Risk estimation for possible risk factors for HCV infection Among Diabetics Type 2 at Sharkia governorate

\begin{tabular}{lccccc}
\hline & OR & \multicolumn{3}{c}{$\mathbf{9 5 \%}$ CI } & p \\
\hline Age (55-65) years & 1.929 & 1.365 & - & 2.725 & $\mathbf{0 . 0 0 0 2 * *}$ \\
\hline Male & 1.375 & 0.971 & - & 1.948 & 0.072 \\
\hline Rural residence & 1.155 & 0.835 & - & 1.597 & 0.873 \\
\hline Smoking & 1.049 & 0.632 & - & 1.741 & 0.852 \\
\hline Low SES & 1.462 & 1.056 & - & 2.023 & $\mathbf{0 . 0 2 1} *$ \\
\hline primary education & 2.08 & 1.462 & - & 2.965 & $\mathbf{0 . 0 0 0 1 *}$ \\
\hline Previous Blood transfusion & 1.823 & 1.270 & - & 2.616 & $\mathbf{0 . 0 0 1 1 ^ { * }}$ \\
\hline Dental maneuvers & 1.366 & 0.993 & - & 1.88 & 0.0551 \\
\hline Sharing personal utensils & 1.859 & 1.108 & - & 3.117 & $\mathbf{0 . 0 1 8 7 ^ { * }}$ \\
\hline Previous hospitalization & 1.676 & 1.955 & - & 2.349 & $\mathbf{0 . 0 0 2 7}$ \\
\hline Previous operations & 1.342 & 0.970 & - & 1.855 & 0.0749 \\
\hline Parenteral Antibilharzial & 1.705 & 1.174 & - & 2.476 & $\mathbf{0 . 0 0 5 0}$ \\
\hline Previous delivery & 2.067 & 0.424 & - & 10.07 & 0.3685 \\
\hline CS & 1.434 & 0.957 & - & 2.149 & 0.0803 \\
\hline Insulin injection & 1.593 & 1.117 & - & 2.273 & $\mathbf{0 . 0 1 0 1 *}$ \\
\hline Neurological & 1.084 & 0.773 & - & 1.521 & 0.6380 \\
\hline Cardiovascular & 0.943 & 0.676 & - & 1.315 & 0.346 \\
\hline Ophthalmological & 1.634 & 0.884 & - & 3.018 & 0.1166 \\
\hline Renal & 0.996 & 0.475 & - & 2.090 & 0.9930 \\
\hline Diabetic foot & 0.922 & 0.518 & - & 1.641 & 0.783 \\
\hline Dental & 1.352 & 0.983 & - & 1.861 & 0.0635 \\
\hline Family members HCV & 1.607 & 1.143 & - & 2.260 & $\mathbf{0 . 0 0 6 4 *}$ \\
\hline Overweight & 1.101 & 0.797 & - & 1.521 & 0.5582 \\
\hline HbAlc & 1.233 & 0.886 & - & 1.717 & 0.213 \\
\hline & & & & & \\
\hline
\end{tabular}


Table (4) :Logistic regression analysis for possible risk factors as predictors of $\mathrm{HCV}$ infection in studied cross section $(\mathrm{N}=642)$

\begin{tabular}{|c|c|c|c|c|c|c|c|}
\hline & $\begin{array}{l}\text { Regression } \\
\text { Coefficient }\end{array}$ & SE & OR & \multicolumn{3}{|c|}{$95 \% \mathrm{CI}$} & $p$ \\
\hline$\overline{A g e}$ & +0.108 & 0.154 & 1.11 & 0.82 & - & 1.50 & 0.481 \\
\hline Residence & -0.174 & 0.176 & 0.84 & 0.59 & - & 1.18 & 0.324 \\
\hline SES & -0.582 & 0.188 & 0.55 & 0.38 & - & 0.80 & 0.002* \\
\hline Family size & +0.073 & 0.093 & 1.07 & 0.89 & - & 1.29 & 0.432 \\
\hline $\begin{array}{l}\text { Previous Blood } \\
\text { transfusion }\end{array}$ & +0.610 & 0.220 & 1.84 & 1.19 & - & 2.83 & $0.006 *$ \\
\hline Dental maneuvers & +21.129 & $28,420.80$ & $\begin{array}{c}1,500,823 \\
, 369.3\end{array}$ & 0.00 & - & --- & 0.999 \\
\hline $\begin{array}{l}\text { Sharing personal } \\
\text { utensils }\end{array}$ & +0.965 & 0.477 & 2.62 & 1.03 & - & 6.68 & $0.043 *$ \\
\hline $\begin{array}{l}\text { Previous } \\
\text { hospitalization }\end{array}$ & +0.713 & 0.363 & 2.04 & 1.00 & - & 4.15 & $0.049 *$ \\
\hline Previous operations & -0.666 & 0.345 & 0.51 & 0.26 & - & 1.01 & 0.054 \\
\hline $\begin{array}{l}\text { Parenteral } \\
\text { Antibilharzial }\end{array}$ & +0.599 & 0.270 & 1.82 & 1.07 & - & 3.09 & $0.027 *$ \\
\hline Delivery mode & +0.497 & 0.262 & 1.64 & 0.98 & - & 2.74 & 0.058 \\
\hline DM duration & +0.010 & 0.022 & 1.01 & 0.96 & - & 1.05 & 0.642 \\
\hline$D M t t$ & +0.187 & 0.197 & 1.20 & 0.81 & - & 1.77 & 0.343 \\
\hline Neurological & +0.493 & 0.260 & 1.63 & 0.98 & - & 2.72 & 0.058 \\
\hline Cardiovascular & -0.027 & 0.244 & 0.97 & 0.60 & - & 1.57 & 0.913 \\
\hline Ophthalmological & +0.475 & 0.470 & 1.60 & 0.64 & - & 4.03 & 0.312 \\
\hline Renal & -0.891 & 0.647 & 0.41 & 0.11 & - & 1.46 & 0.169 \\
\hline Diabetic foot & -0.804 & 0.501 & 0.44 & 0.16 & - & 1.19 & 0.109 \\
\hline Dental & -20.951 & $28,420.80$ & 0.00 & 0.00 & - & --- & 0.999 \\
\hline $\begin{array}{l}\text { Family members with } \\
\mathrm{HCV}\end{array}$ & +0.469 & 0.190 & 1.59 & 1.10 & - & 2.31 & 0.013* \\
\hline$B M I$ & -0.138 & 0.111 & 0.87 & 0.70 & - & 1.08 & 0.215 \\
\hline HbAlc & -0.138 & 0.093 & 0.87 & 0.72 & - & 1.04 & 0.135 \\
\hline
\end{tabular}

\section{DISCUSSION}

Hepatitis $\mathrm{C}$ virus $(\mathrm{HCV})$ infection is a major public health challenge in Egypt. It is estimated that $\mathrm{HCV}$ prevalence among the 15-59 years age group to be $14.7 \%$ which is said to be the highest prevalence in the world. The origin of the HCV epidemic in Egypt has been attributed to intravenous schistosomiasis treatment in rural areas in the 1960s-70s ${ }^{(2)}$.

A large part of the Ministry of Health budget is spent on treatment of $\mathrm{HCV}$ virus and its complications, so multiple studies were conducted among different population groups in Egypt over the last two decades to assess the distribution of infection in the population, risk factors of infection and to help its control. Many studies have been done in different parts of the world proved that there is a mutual relation between hepatitis c virus and diabetes mellitus.
As hepatitis $\mathrm{C}$ infection is endemic in Egypt specially in Sharkia governorate ${ }^{(14)}$, It becomes very necessary for a screening exercise to determine the prevalence rate of HCV antibodies among diabetic patients type 2 in Sharkia governorate and the most important risk factors for HCV infection in those patient and if there is a relation to some demographic parameters, diabetes control or its complications.

The present study showed that the overall prevalence of $\mathrm{HCV}$ antibodies in type 2 diabetic patient at Sharkia governorate is $38.7 \%$ which is much higher than that reported by The Egypt Demographic and Health Survey (2008 EDHS), which stated that the prevalence of $\mathrm{HCV}$ in general population is $14.7 \%$ among a nationally representative sample of 11,126 Egyptians aged 15-59 years old.

The higher prevalence of HCV antibodies in type 2 diabetic patients than general population is in 
agreement with previous studies that have noted a 2- to 10-fold increase in the sero-prevalence of $\mathrm{HCV}$ infection in diabetic patients ${ }^{(\mathbf{1 5})(\mathbf{1 6})}$. Also in a study conducted in 2004, Custro et al. ${ }^{(17)}$ stated that, about $42.3 \%$ of the patients with impaired glucose tolerance were infected with HCV. This may be in part due to increased risk of exposure to $\mathrm{HCV}$ infection or as chronic $\mathrm{HCV}$ is usually associated with hepatic steatosis, insulin resistance and decrease of adiponectine synthesis that all predispose persons chronically infected with HCV to gradual development of DM2 ${ }^{(11)}$.

It was observed from our study that there was a significant association between age \& risk of $\mathrm{HCV}$ exposure in type 2 diabetic patient, where the mean age of the $\mathrm{HCV}$ ab negative patients was 51.99 while that in HCV positive cases is 55.55. More than $75 \%$ of $\mathrm{HCV}$ positive patient in the study lies between $45 \& 65$ years old, This result is in agreement with that obtained by Mohamoud et al. (2013) ${ }^{(\mathbf{1 8})}$ who reported that the prevalence of $\mathrm{HCV}$ appears to increase dramatically with age with the highest rates observed among populations aged greater than 40 years.

The prevalence of HCV infection in males and females were found to be $44.2 \%$ and $36.6 \%$, respectively, however this difference did not reach statistical significance $(\mathrm{P}=0.159)$, indicating that gender plays no role in the prevalence of $\mathrm{HCV}$ infection among diabetic type 2 patients.

The absence of a relationship between residence of the patients and the prevalence of infection in Sharkia governorate is not in agreement with many studies which reported higher prevalence in

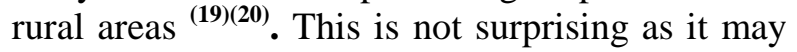
be in part due to the agriculture nature of Sharkia governorate and on other part it reflects the rural immigration to urban areas because of the close proximity of urban and rural areas, actually there is no sharp demarcation between inhabitants of cities and villages.

Socioeconomic level and educational level have a major role in $\mathrm{HCV}$ prevalence in type 2 diabetic patients, where HCV infection was commonly affect patients with low socioeconomic level and those of low education level. This may be due to wrong habits and misbelieve predominate in this category of lower educational standard and illiteracy that include; non-sanitary measures, non- sterilized medical procedures like IV injections, paramedical circumcisions, common shaving by public barbers, paramedical ear piercing, tattoo acupuncture and nail cutter sharing. Familial clustering and overcrowding may add more risks for HCV transmission.

Although family Size in HCV ab positive patients in this study is higher than that of HCV ab negative patients but this was not of statistical significance.

There was significant association between family members infected with $\mathrm{HCV} \&$ exposure to $\mathrm{HCV}$ infection, where $\mathrm{HCV}$ commonly infects patients who have family members infected with $\mathrm{HCV}$. This is in agreement with that stated by Plancoulaine et al. (2008) ${ }^{(21)}$ who reported a highly significant intra-familial resemblances in $\mathrm{HCV}$ sero-prevalence between father-offspring, mother-offspring, and sibling-sibling. There was greater $\mathrm{HCV}$ strain similarity between family members than between unrelated subjects which can be explained, by familial sources of virus transmission.

Sharing personal utensils like tooth brushes, shaving razors, tattoo acupuncture and nail cutter and paramedical ear piercing and during paramedical circumcision have significant association with the occurrence of $\mathrm{HCV}$ infection. This result is in agreement with that reported by Arafa et al. (2005) ${ }^{(19)}$ who concluded that Community and informal health provider related exposures were associated with increased $\mathrm{HCV}$ infection.

The significant association between previous blood transfusion\& occurrence of $\mathrm{HCV}$ infection, is in agreement with that reported by Abdelwahab et al. (2012) ${ }^{(22)}$ who stated that $\mathrm{HCV}$ prevalence rates are higher among previously transfused patients. This might be before the era of blood testing for viruses in blood banks or the blood donor carrying HCV virus but in the incubation period which not appear in the laboratory testing (false negative $\mathrm{HCV}-\mathrm{Ab}$ by ELISA).

The significant association between previous hospitalization \& exposure to $\mathrm{HCV}$ infection is in agreement with that reported by Kandeel et al. (2012) ${ }^{(23)}$ who stated that health care exposures are important source of ongoing $\mathrm{HCV}$ transmission in Egypt due to apparent break in standard precautions during minor procedures such as administration of IV fluids, suturing, and conducting minimal surgeries.

The non-significant association between previous operation, previous delivery or mode of delivery $\&$ the occurrence of $\mathrm{HCV}$ infection which is in agreement with that stated by Esmat et al. (2013) (24) that most major surgical interventions are done at the better-supplied hospitals and healthcare facilities, HCV exposures due to surgical 
interventions were less likely to occur and when they did, the viral exposure was lower, resulting in a greater likelihood of spontaneous clearance. This may explain how surgical interventions were the highest risk for $\mathrm{HCV}$ acquisition, but not for $\mathrm{HCV}$ persistence.

Although the prevalence of $\mathrm{HCV}$ antibodies in type 2 diabetic patients who had dental maneuvers is higher than those who did not have but this did not touch the significant level. This was not in agreement with previous studies documented the role of dental maneuvers in transmission of $\mathrm{HCV}$ as that done by Farghaly et al. (1998) ${ }^{(25)}$. This may be explained by following infection control measures in dental clinics which help to decrease the role of dental maneuvers' as risk factors for HCV transmissions.

The significant association between history of previous receiving parenteral anti-bilharzial therapy \& exposure to $\mathrm{HCV}$ infection is in agreement with many studies which stated that parenteral anti-bilharzial campaigns to control schistosomiasis are the major drivers of the $\mathrm{HCV}$ epidemic in Egypt due to reuse of glass syringes and lax sterilization practices ${ }^{(\mathbf{1 4})(26)}$.

The significant association between type of diabetes mellitus treatment \& occurrence of HCV infection may be due to the use of unsterile syringes and those patients are more liable to diabetes complication's and hospital admission than those using oral therapy for diabetes so they are more prone to HCV infection.

The present study showed that there was no significant association between diabetes control checked by HbA1c level \& occurrence of HCV infection and even diabetes complication like neurological, cardiovascular, ophthalmological, renal, dental or diabetic foot also have no significant association with HCV prevalence.

In this study most of the type 2 diabetic patients were overweight or obese but no significant association were detected between degree of obesity measured by BMI \& occurrence of $\mathrm{HCV}$ infection.

It was observed from our study that there was significant difference in duration of diabetes mellitus between patient who have $\mathrm{HCV}$ infection \& patients have not $\mathrm{HCV}$ infection, where $\mathrm{HCV}$ infection tend to occur more commonly in patients with longer duration of diabetes mellitus, This is in agreement with that stated by Skowronski et al. (2006) (27) that HCV replication may be favored by hyper-insulinemia and/or the increased serum levels of free fatty acids observed in patients with IR and type 2 DM additionally. Type $2 \mathrm{DM}$ is, to some extent, associated with an immune-compromised state, which leads to derangements of immune function.

Using univariate analysis, HCV is highly prevalent in age group 45-65 years, low socioeconomic level patients, low educated patients, patients sharing personal utensils ,family members with HCV patients, who received previous blood transfusion or parenteral anti-bilharzial treatment, previous hospitalized patients, and those treated by insulin injection .

Using multivariate logistic regression analysis, the most significant independable factors associated with development of $\mathrm{HCV}$ in type II diabetes mellitus patients were the following:

The most important factor associated with $\mathrm{HCV}$ infection is socioeconomic standard; as lower socio economic level may predispose to increase risk of $\mathrm{HCV}$ infection in type 2 diabetic patients and higher socio economic standard is less exposed to $\mathrm{HCV}$ infection $(\mathrm{P}=0.002)$. This is in agreement with that stated by Medhat et al. (2002) ${ }^{(28)}$ that the community-acquired practices in low socio economic standard people help of HCV transmission in Egypt.

Previous blood transfusion is the second most important risk factor for $\mathrm{HCV}$ transmission in type 2 diabetic patients $(\mathrm{P}=0.006)$ this is in agreement with that stated by El-Sadawy et al. (2004) (14) that there is strong correlations between $\mathrm{HCV}$ infection and receiving blood transfusion.

Family members infected with $\mathrm{HCV}$ is considered the third most Common factor associated with $\mathrm{HCV}$ infection among diabetic patients type 2 at Sharkia governorate. Sharing the same living conditions may have a role in exposure of family members to $\mathrm{HCV}$ infection as (sharing personal utensils, minor operations in non-qualified centers, same socio economic level ......)

Parenteral anti-bilharzial treatment is considered the fourth most Common factor associated with $\mathrm{HCV}$ infection among diabetic patients type 2 in Sharkia governorate as patients received PAT are 1.8 times more likely to have $\mathrm{HCV}$ infection than those who did not receive $(\mathrm{P}=0.027)$. This is in agreement with previous study by El-Sadawy et al. (2004) ${ }^{(\mathbf{1 4})}$ who stated that previous parenteral therapy for schistosomiasis was significant predictor of $\mathrm{HCV}$ infection at Sharkia governorate.

Patients sharing personal utensils are 2.6 times more likely to have $\mathrm{HCV}$ infection so it is important risk factor for $\mathrm{HCV}$ transmission among type 2 diabetic patients at Sharkia governorate (P $=0.043$ ). 
Previous hospitalization is another important risk factor for $\mathrm{HCV}$ transmission in type 2 diabetic patients at Sharkia governorate $(\mathrm{P}=0.0493)$. This is in agreement with that reported by Forns et al. (2008) (29) that hospitalization for any cause increase the possibility of acquiring $\mathrm{HCV}$ infection particularly in developing countries.

Interestingly, the results showed that only $48.6 \%$ of $\mathrm{HCV}$ ab positive patients know that they have the infection and more than $50 \%$ of $\mathrm{HCV}$ patients discovered by this study, this demonstrates the importance of screening programs for $\mathrm{HCV}$ in Egypt population especially type 2 diabetic patients.

Of those who know that they have HCV infection only 9.9 had been received interferon and ribavirin therapy while the other $90 \%$ of the patients did not receive the proper treatment due to either ignorance by the treatment or they think that the liver support and vitamins is a treatment for the virus or the virus may not cause any health problems to them or fear from the interferon side effects.

\section{CONCLUSION AND RECOMMENDATION}

This study draw attention to the surprisingly higher prevalence of HCV in type 2 diabetic patients at Sharkia governorate and it is an effort to highlight the risk factors for this higher prevalence

\section{We recommend:}

- Screening of type 2 diabetic patients for $\mathrm{HCV}$ antibodies is highly recommended due to high prevalence in this group of patients.

- Screening is mandatory in high risk patients (low socioeconomic standard, previous blood transfusion, Family members infected with HCV, Receiving Parenteral Anti-bilharzial treatment, sharing personal utensils and previous hospitalization).

- Improving socioeconomic standard and educational level may limit spread of many infectious diseases as HCV virus.

- Health education to increase population awareness about mode of HCV transmission and risk of sharing personal utensils.

- More attention to Sharkia governorate regarding the amount of the new $\mathrm{HCV}$ treatment e.g. sofosbuvir to the patients.

- Further studies should be performed to investigate if the new HCV treatments will cure DM or improve glycemic control in HCV patients develop sustained virological response.

\section{REFERENCES}

1. Shinn-Jang $H$ and Liang-Kung C (2006): Chronic Hepatitis C and Diabetes Mellitus. J Chin Med Assoc, 69(4):143-145.

2. El-Zanaty F and Way A (2009): Egypt Demographic and Health Survey 2008. Ministry of Health (El-Zanaty and Associates and Macro International, 2009: p. 431.

3. Guariguata L, Whiting DR, Hambleton I et al.(2014): Global estimates of diabetes prevalence for 2013 and projections for 2035 for the IDF Diabetes Atlas Diabetes Res Clin Pract. 2014 Feb;103(2):137-49.

4. Ahmadieh H and Azar ST. (2014): Liver disease and diabetes Association, pathophysiology, and management. Diabetes Res Clin Pract ,2014 104(1):53-62.

5. Shaw JE, Sicree RA, Zimmet PZ. (2010): Global estimates of the prevalence of Diabetes for 2010 and 2030. Diabetes Res Clin Pract. Jan;87(1):4-14.

6. Blachier M, Leleu H, Peck-Radosavljevic M et al.(2013): The burden of liver disease in Europe: a review of available epidemiological data. The European Association for the Study of the Liver 2013; 978-2-8399-1176-4

7. Caldwell SH, Oelsner DH, Iezzoni JC, et al. (1999): Cryptogenic cirrhosis: clinical characterization and risk factors for underlying disease. Hepatology; 1999 Mar; 29 (3):664-9.

8. Taliani G, Poliandri G, Clementi $G$ et al. (1992): Chronic Hepatitis C and diabetes mellitus Hepatol 16 (Suppl): S116.

9. Chehadeh W, Abdella N, Ben-Nakhi A et al. (2009): Risk factors for the development of diabetes mellitus in chronic hepatitis $\mathrm{C}$ virus genotype 4 infection. J Gastroenterol Hepatol: 2009 24(1):42-8.

10. Imazeki F, Yokosuka O, Fukai $\mathrm{K}$, et al. (2008): Prevalence of diabetes mellitus and insulin resistance comparison with hepatitis $\mathrm{B}$-vial in virus-infected and hepatitis $\mathrm{C}$ viruscleared patients. Liver Int. ; 28:355-362.

11. Jean-Michel P, Minello A, Jooste V et al (2005): Decreased Plasma Adiponectin Concentrations Are Closely Related to Steatosis in Hepatitis C Virus-Infected Patients. J. Clin. Endocrinol. Metab. 90:224043.

12. Caronia S, Taylor K, Pagliaro L, et al. (1999): Further evidence for an association between non- insulin-dependent diabetes mellitus and chronic hepatitis $\mathrm{C}$ virus infection. Hepatology;1999 Oct; 30(4):1059-65. 
13. Elhawary E, Mahmoud G, EL Daly M et al(2011): Association of HCV with diabetes mellitus: an Egyptian case-control study. Virology Journal 8:367.

14. El-Sadawy M, Ragab H, El-Toukhy $\mathrm{H}$ et al (2004): Hepatitis C virus infection at Sharkia Governorate, Egypt: seroprevalence and associated risk factors. J Egypt Soc Parasitol, 34(1):367-384.

15. Mason AL, Lau JY, Hoang N et al. (1999): Association of diabetes mellitus and chronic hepatitis $\mathrm{C}$ virus infection. Hepatology 1999;29:328-33.

16. Gray H, Wreghitt T, Stratton IM, et al.(1995): High prevalence of hepatitis $\mathrm{C}$ infection in Afro-Caribbean patients with type 2 diabetes and abnormal liver function tests. Diabet Med 1995; 12: 244-9.

17. Custro N, Carroccio A, Ganci A et al. (2004): Glycemic homeostasis in chronic viral hepatitis and liver cirrhosis. Diabetes Metab. 27(4 Pt 1): 476-81.

18. Mohamoud Y A, Ghina R Mumtaz, Suzanne Riome et al. (2013): The epidemiology of hepatitis $\mathrm{C}$ virus in Egypt. BMC Infectious Diseases 13:288.

19. Arafa N, El Hoseiny M, Rekacewicz C, et al. (2005): Changing pattern of hepatitis $C$ virus spread in rural areas of Egypt. J Hepatol, 43(3):418-424.

20. Habib M, Mohamed MK, Abdel-Aziz F et al. (2001): Hepatitis C virus infection in a community in the Nile Delta: Risk factors for seropositivity. Hepatology, 33(1):248-253.

21. Plancoulaine S, Mohamed MK, Arafa N et al (2008): Dissection of familial correlations in hepatitis C virus (HCV) seroprevalence suggests intrafamilial viral transmission and genetic predisposition to infection. Gut, 57(9):1268-1274.

22. Abdelwahab MS, El-Raziky MS, Kaddah NA, et al. (2012): Prevalence of hepatitis $C$ virus infection and human immunodeficiency virus in a cohort of Egyptian hemophiliac children. Ann Saudi Med 2012, 32(2):200-2.

23. Kandeel A M , Talaat M, Salma AF et al. (2012): Case control study to identify risk factors for acute hepatitis $\mathrm{C}$ virus infection in Egypt. BMC Infectious Diseases 2012; 12:294.

24. Esmat G, Hashem M, El-Raziky et al ( 2013): Risk Factors for Hepatitis C Virus Acquisition and Predictors of Persistence among Egyptian Children. Liver Int.; 32(3): 449-456.

25. Farghaly AG, Mansour GA, Mahdy NH, et al. (1998): Hepatitis B and C virus infections among patients with gingivitis and adult periodontitis: seroprevalence and public health importance. J Egypt Public Health Assoc 1998, 73(5-6):707-735.

26. Yahia M (2011): Global health: A uniquely Egyptian epidemic. Nature; 2011 Jun 8;474(7350):S12-3.

27. Skowronski, M., Zozulinska, D., Juszczyk, J. et al.(2006): Hepatitis C virus infection: evidence for an association with type 2 diabetes. Diabetes Care; 2005 Oct; 28(10):2548-50.

28. Medhat A, Shehata M, Magder LS, et al (2002) : Hepatitis C in a community in Upper Egypt: risk factors for infection. Am J Trop Med Hyg, 66:633-638.

29. Forns M, Armelles R, Planas R, et al ( 2008 ): Hospital admission is a relevant source of hepatitis $\mathrm{C}$ virus acquisition in Spain. $\mathrm{J}$ Hepatol, 48:20-27. 